\title{
Micronucleus Test in Exfoliated Buccal Cells of Barbecue Grillers in Marawi City, Philippines
}

\author{
Abdul Baari’ M. Guma-os ${ }^{\# 1}$, Annabella G. Villarino ${ }^{\# 2}$ \\ ${ }^{\# 1}$ College of Medicine, Mindanao State University, Marawi City \\ ${ }^{\# 2}$ Biology Department, Mindanao State University, Marawi City
}

\begin{abstract}
Exposure to fumes when grilling meat predisposes human to a significant level of cancer-causing compounds called PAHs (Polycyclic Aromatic Hydrocarbons. The DNA damaging capacity of PAHs can be rapidly and inexpensively evaluated by measuring and counting the micronuclei in various cells. In this study, the frequency of micronucleation $(M N)$ in exfoliated buccal epithelial cells of thirty $(N=30)$ barbecue grillers (exposed group) in Marawi City was compared with thirty $(N=30)$ office workers and students of Mindanao State University (control). A total of 1000 buccal epithelial cells per individual were scored for MN frequency. Results revealed a significant increase $(p<0.05)$ in the MN frequency of barbecue grillers $(18.97 \pm 3.77)$ compared with the control (12.6 \pm 3.58$)$. In addition, possible effect of the established confounders which include smoking, drinking habits, age, gender and number of years of exposure to PAHs on the frequency of micronucleation was further analysed. Confounding factors that could have caused higher MN frequency in the exposed group are age $(\rho=0.000)$ and length of exposure to grilling fumes $(P=0.002)$. The current study confirms that chronic exposure to grilling fumes increases micronucleation, hence the necessity of biological monitoring and appropriate health interventions.
\end{abstract}

Keywords: Marawi City, micronucleus, barbecue grillers, Polycyclic Aromatic Hydrocarbons

\section{INTRODUCTION}

Barbecuing or charcoal-grilling is a popular outdoor cooking activity of Filipinos, however, potential health hazards associated with the inhalation of barbecue fumes have yet to be determined. Numerous researches have shown that exposure to heterocyclic amines (HCAs) and polycyclic aromatic hydrocarbons (PAHs) contained in barbecue fumes may increase the risk of developing certain kinds of cancer and many other ill-effects (Health Effects Institute 2010, Anderson et al, 2002 ). Genetic damage due to lifestyle characteristics, occupational exposure, diseases and environmental risk can be assayed through the use of the buccal micronucleus test. Micronuclei are structures similar to the cell's nucleus that arise from chromosome fragments or whole chromosomes that lag behind at anaphase during nuclear division (Holland et al., 2008). The frequency of micronucleus formation in the cells has been believed to be correlated with the increasing effects of carcinogens (Naderi et. al, 2012). Buccal cells can be used to assay DNA damage caused by carcinogenic substances since they are the first barrier during inhalation or ingestion route.

This research was conducted to evaluate DNA damage of exfoliated buccal cells among barbecue grillers through micronucleus test. Specifically this study sought to answer the following questions: (1) would constant exposure to barbecue fumes cause a significant increase in micronucleus frequency in the buccal cells of barbecue grillers? (2) do confounding factors such as smoking, drinking habits, age, gender and number of years of exposure to barbecue fumes increases the frequency of micronuclei in the buccal cells of the barbecue grillers?

\section{METHODOLOGY}

\section{A. STUDY DESIGN}

This study employed a descriptive cross-sectional study to assess the DNA damage of the exfoliated buccal cells among barbecue grillers exposed to grilling fumes. The sampling sites for the occupationally exposed 
group were Baririo Paypay of Marawi City where most of the barbecue grillers are located. Comprising the control group were residents of Mindanao State University-Main Campus, Marawi City.

\section{B. STUDY SUBJECTS}

All the participants (N-60) comprising the control $(n=30)$ and exposed $(n=30)$ groups were selected by employing purposive sampling. Individuals composing the occupationally exposed group were chosen based on the following criteria: (1) must be male or female barbecue grillers and vendor of Marawi City (2) must be constantly exposed to barbecue fumes at least 5 days a week for a minimum of 4 hours daily. The control group $(n=30)$ were aged-matched individuals which are not barbecue grillers, hence minimal exposure to occupational or environmental fumes like the students, office workers, instructors, and other residents of MSU-Main Campus, Marawi City. A total of sixty (60) individuals participated in the study. Prior to data collection, the study participants were informed of the purpose of the study. This was done to ensure that the participants understood the data collection procedure. Those who agreed to participate were then asked to sign an informed consent form and to fill out a questionnaire to obtain necessary information on their lifestyle and personal factors (age, length of exposure, smoking habits, drinking habits, etc.). The questionnaire was patterned from the protocol published by the International Commission for Protection against Environmental Mutagens and Carcinogens (Carrano and Natarajan, 1988) with modifications. The participants were coded to ensure their anonymity.

\section{BUCCAL MICRONUCLEUS TEST}

The assay protocol used in this research was adapted from Sellappa et.al (2011). Prior to buccal cell sample collection, the participants rinsed their mouths with distilled water to remove any unwanted debris. Buccal cells were collected by rubbing an extra soft toothbrush in the inner sides of both cheeks for 30seconds and then rinsing the mouth with $20 \mathrm{ml}$ of $0.9 \%$ saline solution. The gargled solution was expectorated into sterile test tubes and was transferred into centrifuge tubes containing Phosphate Buffered Saline (PBS) at pH 7.0, creating a cell suspension. The cells were washed three times by centrifugation at $1500 \mathrm{rpm}$ for 10 mins in the buffer solution. After discarding the supernatant, the pellet was smeared on clean microscope slides and allowed to air dry for 5-10 min. The slides were fixed in cold methanol: acetic acid (3:1) for 15 minutes, air-dried, and stained with $5 \%$ Giemsa for 20 minutes. The slides were then rinsed with distilled water; air dried and viewed under the light microscope. Six slides were prepared per sample. A total of 1000 cells per individual were scored for micronuclei frequency.

The buccal micronuclei (MN) were scored based on the criteria established by Tolbert et.al. (1992): (1) MN must be less than one third the diameter of the main nucleus; (2) must be on the same focal plane; (3) must have the same color, texture, and refraction as the main nucleus; (4) must have a smooth oval or round shape; and (5) must be clearly separated from the mainnucleus. A micronucleated cell rate over $8 \%$ is considered abnormal. Only non-fragmented, non- accumulated, non-overlaid cells, as well as those cells containing an intact nucleus were considered for scoring. The frequency of other degenerative nuclear changes such as binucleated cells, nuclear bud, karyolysis, pyknosis, and karyorrhexis were not included in the analysis.

\section{CONFOUNDING FACTORS}

To account for the confounding factors of this study, the experimental and control groups were classified as smokers and non-smokers; alcoholics and non-alcoholics; tea drinker and non-tea drinker; and coffee drinker and non-coffee drinker respectively. The aforementioned factors were considered, since a number of studies suggest that these factors may affect the frequency of micronuclei formation and may contribute to the occurrence of cancer (Bolukbas et.al., 2006; IARC 1997). The subjects who smoke >5cigarettes/day for 1 year were considered as smokers and those who consumed $>120 \mathrm{mg}$ of alcohol/day were considered as alcoholics in both groups (Vasuvedan et. al, 2011). The subjects who drink at least 1 cup of coffee and tea everyday were considered as coffee drinkers and tea drinkers respectively. The length of exposure to grilling fumes was considered for the exposed group. On the other hand, the length of fumes exposure for the controls was set to zero. The basis for the length of fumes exposure was the number of years of working as grillers in Marawi City.

\section{E TREATMENT OF DATA}

The results of this study were statistically analyzed using Statistical Package for the Social Sciences (SPSS) 17.0. Mean and standard deviation (SD) of the micronucleus frequency obtained from scoring were calculated for both exposed and reference groups. The resulting data difference between the exposed and reference groups was further evaluated using Student's $T$ test wherein $p<0.05$ was considered significant. Furthermore, the 
relationship of the confounding variables to micronucleation within the exposed and within the reference groups was analyzed using Spearman's rho correlation.

\section{RESULTS}

The descriptive characteristics of the subjects comprising the exposed and reference groups were summarized in Table 1. The age of the subjects in the compared group were homogenous (mean $=28.6 \pm 11.053$ for the exposed and mean $=26.967 \pm 10.142$ for the reference). As to gender, the ratio of male to female in both groups was 17:13 and majority were non-smokers. Not one of the subjects in the study groups was a tea drinker but most subjects were coffee drinkers. No data was accounted for alcohol drinking, since none of the test subject consumed $>120 \mathrm{mg}$ of alcohol/day.

Micronuclei frequency (MN) in the exfoliated buccal cells (Figure 2) were scored for both exposed and reference groups (Figure 1). The results showed that the MN frequency (18.97 \pm 3.77 vs $12.6 \pm 3$ of the barbecue vendors and reference individuals differed significantly $(\rho<0.001)$.

The possible correlation of the confounding factors with micronuclei frequency revealed that in the exposed group, only age $(\rho=0.000)$ and length of exposure $(\rho=0.002)$ to the fumes showed a statistically significant relationship. While for the reference group, only the factors, age and smoking habit showed statistically significant relationship with micronuclei frequency ( $\rho=0.000$ for age and $\rho=0.014$ for smoking).

Table 1. Descriptive characteristics of the study population

\begin{tabular}{|c|c|c|}
\hline Variables & Exposed $(n=30)$ & Control $(n=30)$ \\
\hline $\begin{array}{ll}\text { Age: } & \text { Minimum } \\
& \text { Maximum } \\
& \text { Mean } \pm S D \\
\end{array}$ & $\begin{array}{c}13 \\
55 \\
28.6 \pm 11.053 \\
\end{array}$ & $\begin{array}{c}18 \\
52 \\
26.967 \pm 10.142 \\
\end{array}$ \\
\hline $\begin{array}{c}\text { Length of Exposure: } \\
\text { Minimum } \\
\text { Maximum } \\
\text { Mean } \pm \text { SD }\end{array}$ & $\begin{array}{l}2 \text { months } \\
22 \text { years } \\
6.26 \pm 6.59\end{array}$ & $\begin{array}{l}0 \\
0 \\
0\end{array}$ \\
\hline Gender: $\begin{array}{c}\text { Male } \\
\text { Female }\end{array}$ & $\begin{array}{l}17(56.67 \%) \\
13(43.33 \%)\end{array}$ & $\begin{array}{c}17(56.67) \\
13(43.33 \%)\end{array}$ \\
\hline $\begin{array}{c}\text { Smoking Habits: } \\
\text { Yes } \\
\text { No }\end{array}$ & $\begin{array}{c}8(26.67 \%) \\
22(73.33 \%) \\
\end{array}$ & $\begin{array}{c}5(16.67 \%) \\
25(83.33 \%) \\
\end{array}$ \\
\hline $\begin{array}{l}\text { Recently ill: } \\
\text { Respiratory-related disease } \\
\text { Fever } \\
\text { None }\end{array}$ & $\begin{array}{c}1(3.33 \%) \\
1(3.33 \%) \\
28(93.33 \%)\end{array}$ & $\begin{array}{c}0(0 \%) \\
0(0 \%) \\
30(100 \%)\end{array}$ \\
\hline $\begin{array}{c}\text { Coffee Drinker: } \\
\text { Yes } \\
\text { No }\end{array}$ & $\begin{array}{c}25(83.33 \%) \\
5(16.67 \%)\end{array}$ & $\begin{array}{c}30(100 \%) \\
0(0 \%)\end{array}$ \\
\hline $\begin{array}{r}\text { Tea Drinker: } \\
\text { Yes } \\
\text { No }\end{array}$ & $\begin{array}{c}0(0 \%) \\
30(100 \%)\end{array}$ & $\begin{array}{c}0(0 \%) \\
30(100 \%)\end{array}$ \\
\hline $\begin{aligned} \text { Alcoholic: } & \\
& \text { Yes } \\
& \text { No }\end{aligned}$ & $\begin{array}{c}0(0 \%) \\
30(100 \%)\end{array}$ & $\begin{array}{l}0(0 \%) \\
30 \quad 100 \%)\end{array}$ \\
\hline
\end{tabular}

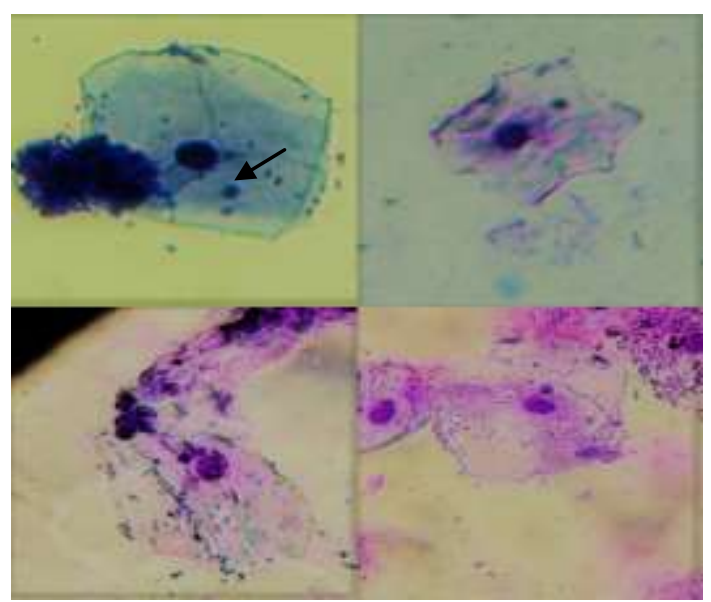

Figure 2. Micronucleated buccal epithelial cells (1000x magnification). 


\section{DISCUSSION}

Several epidemiologic studies indicate that direct exposure to barbecue fumes causes DNA damage and a wide variety of adverse health effects (Ng \& Tan, 1994; Ng \& Tan 1993; Ko et al., 1997; Notani et al., 1993). Moreover, The International Agency for Research on Cancer (IARC) have stated that PAHs, HCAs and aldehydes are of particular concern in relation to carcinogenicity caused by barbecue fumes (IARC 2012).

Exfoliated cells of the buccal mucosa are at greater risk to DNA damage due to their frequent exposure to genotoxic substances (Holland, et al. 2008). Furthermore, the cells of the oral cavity are capable of metabolizing carcinogens to reactive forms. The genotoxicity of fumes can be attributed to its hazardous chemical components like PAHs which can generate excessive reactive oxygen species causing oxidative stress hence DNA damage (Krivoshto et. al., 2008; Li \& Nel, 2006). In addition, the reactive metabolites of Polycyclic Aromatic Hydrocarbons (PAHs) have the ability to bind to cellular proteins and DNA resulting in increased frequency of mutation and DNA strand breakage (Lah, 2011 and Li \& Nel, 2006). Unrepaired DNA breaks cause micronucleus formation when the cell fails to repair the DNA because the DNA damage load is too much for the cell to handle within the specified time frame. Another mechanism of micronuclei formation due to chromosome fragments is the simultaneous excision repair of damaged or inappropriate bases incorporated in DNA that are in proximity and on opposite complementary DNA strands. Aside from chromosome fragments, micronuclei can also arise from whole lagging chromosomes. This may happen due to a wide array of mechanisms including hypomethylation of repeat sequences in centromeric and pericentromeric DNA, defects in kinetochore proteins or assembly, dysfunction spindle, and defective anaphase checkpoint genes.

The results of this study showed that barbecue fumes exposure has a significant effect on the micronuclei frequency of the barbecue vendors. This is in agreement with previously concluded studies which also assayed the effects of fumes exposure to occupationally exposed individuals ( $\mathrm{Ng}$ and Tan 1994; $\mathrm{Ng}$, Hui \& Tan 1993; Ko, et al., 1997; Notani, et al. 1993). It is also noted that fumes may interact with exogenous and endogenous factors and influence the frequency of micronuclei formation. Among the exogenous factors are chemicals, physical agents, seasonal changes, viruses, and lifestyle factors such as smoking, drinking habits and nutrition (Major et, al., 1998). Smoking and alcohol drinking are among the factors that have been reported to enhance development of several forms of cancer (Majer et al., 2001). Moreover, endogenous factors such as age and gender may also influence the results of some cytogenetic monitoring (Major et, al., 1998).

\section{CONCLUSION AND IMPLICATION OF THE STUDY}

The barbecue grillers in this study have shown significant increase in the frequency of micronucleated buccal epithelial cells, which indicates that chronic exposure to fumes would increase one's risk to DNA damage and possible carcinogenesis. The genotoxic effect of the barbecue fumes could be further enhanced in individuals with higher ages. It is then recommended that this occupationally exposed population be advised to wear proper protective equipment and take considerable amounts of antioxidants.

\section{ACKNOWLEDGEMENT}

To all those who in one way or the other has made this paper possible. To the researchers and the helping hands of MSU Marawi Biology Department.

\section{REFERENCES}

[1] Anderson K, Sinha R, Kulldorff M, Gross M, Lang N, Barber C, Harnack L, DiMagno E, Bliss R, Kadlubar F.. Meat intake and cooking techniques: associations with pancreatic cancer. Mutation Research, 506-507 pp. 225-31, 2002.

[2] Bolukbas, C., Bolukbas, F., Kocyigit, A., Aslan, M., Selek, S., Bitiren, M., Ulukanligil, M. DNA damage in hepatitis C and B infection. Journal of Gastroenterology and Hepatology, 21, 610-616, 2006.

[3] Carrano A, Natarajan A. International Commission for Protection Against Environmental Mutagens and Carcinogens. ICPEMC publication no. 14. Considerations for population monitoring using cytogenetic techniques, 204(3):379-406, 1988.

[4] Fenech M. Chromosomal biomarkers of genomic instability relevant to cancer. Drug Discovery Today , 7,1128-1137.22 (1): 3-4, 2002 .

[5] Health Effects Institute"A Critical Review of the Literature on Emissions, Exposure, and Health Effects, HEI Special Report 17." Traffic-Related Air Pollution, 2010. 
[6] IARC. IARC: Diesel Engine Exhaust Carcinogenic. Retrieved 2013 September18, from http://www.iarc.fr/en/mediacentre/pr/2012/pdfs/pr213

[7] E.pdf, 2012.

[8] IARC (1997). Coffee, Tea, Mate, Methylxanthines and Methylglyoxal Summary of Data Reported and Evaluation. Retrieved 2018 January, fromhttp://monographs.iarc.fr/ENG/Monographs/vol51/volume51.pdf, 1997.

[9] Ko, YC, et al. "Risk factors for primary lung cancer among non-smoking women in Taiwan." Int J Epidemiol, 26(1), 24-31, 1997.

[10] Krivoshto, I., Richards, J., Albertson, T., \& Derlet, R.. The Toxicity of Diesel Exhaust: Implications for Primary Care. The Journal of the American Board of Family Medicine, 21(1:.55-6, . January-February 2008.

[11] Lah, K. Polycyclic Aromatic Hydrocarbons. http://toxipedia.org/display/toxipedia/polycyclic+Aromatic+Hydrocarbons, 2011.

[12] Li, N. \& Nel, A.E. The cellular imparts impacts of diesel exhaust particles: beyond inflammation and death. European Respiratory Journal, 27(4), 2006.

[13] Majer BJ1, Laky B, Knasmüller S, Kassie F.. Use of the micronucleus assay with exfoliated epithelial cells as a biomarker for monitoring

[14] individuals at elevated risk of genetic damage and in chemoprevention trials. Mutation Research, 489 (2-3):147-72, 2001.

[15] Major, J., Jakab, M.G., \& Tompa, A. Genotoxicological monitoring of 175 subjects living in the green belts, inner town of near chemical industrial estates in Greater Budapest agglomeration, Hungary. Mutation Research, 412, 9-16, 1998.

[16] Naderi, N., Farhadi, S., \& Sarshar, S. Micronucleus Assay of Buccal Mucosa Cells in Smokers with the History of Smoking Less and More than Ten Years. Indian Journal of Pathology and Microbiology, 55 (4): 433-438, 2012.

[17] $\mathrm{Ng}$, TP, and WC Tan.."Epidemiology of allergic rhinitis and its associated risk factors in Singapore." Int J Epidemiol, 23(3), 553-8, 1994.

[18] Ng, TP, KP Hui, and WC Tan . "Respiratory symptoms and lung function effects of domestic." J Epidemiol, 47(6), 454-8, 1993.

[19] Notani, PN, P Shah, K Jayant, and V Balakrishnan. "Occupation and cancers of the lung and bladder:." Int J Epidemiol, 22(2), 185-191, 1993.

[20] Sellappa, S., Prathyumnan, S., Joseph, S., \& Keyan, K.S. Micronucleus Test in Exfoliated Buccal Cells from Chromium Tannery Worker. International Journal of Bioscience, Biochemistry, and Bioinformatics. 1 (1): 59-62, 2011.

[21] Sugimura T, Wakabayashi K, Nakagama H, Nagao M. Heterocyclic amines: Mutagens/carcinogens produced during cooking of meat and fish. Cancer Sci., 95(4):290-9, 2004.

[22] Tolbert P, Shy CM, Allen JW Micronucleus and other nuclear anomalies in buccal smears: Methods development. Mutation Research, 271: 69-77, 1992.

[23] Vasudevan, S., Sellappa, S., Prathyumnan, S., Joseph, S., \&Keyan, K.. Enhanced Micronuclei in Exfoliated Buccal Cells of Tannery Works Exposed to Chromium III (Cr III) in South India. International Conference on Bioscience, Biochemistry and Bioinformatics, Vol. 5, IACSIT Press, Singapore, 2011. 